\title{
Bentuk-Bentuk Perilaku Off-Task dan Upaya Penanganan Guru Kelas di Madrasah Ibtida'iyah
}

\author{
Rine Larang Nur Esanti ${ }^{1}$, M. Ramli ${ }^{2}$, Yuniastuti ${ }^{3}$ \\ ${ }^{1}$ Pendidikan Dasar-Universitas Negeri Malang \\ ${ }^{2}$ Bimbingan dan Konseling-Universitas Negeri Malang \\ ${ }^{3}$ Pendidikan Kewarganegaraan-Universitas Negeri Malang
}

\begin{tabular}{l}
\hline INFO ARTIKEL \\
\hline Riwayat Artikel: \\
Diterima: 03-05-2019 \\
Disetujui: 23-01-2020 \\
\hline Kata kunci: \\
off task behaviour; \\
teacher efforts; \\
islamic school students; \\
perilaku off task; \\
upaya guru kelas; \\
siswa madrasah ibtida 'iyah
\end{tabular}

Alamat Korespondensi:

Rine Larang Nur Esanti

Pendidikan Dasar

Universitas Negeri Malang

Jalan Semarang 5 Malang

E-mail: rinelarang23@gmail.com

\begin{abstract}
This study aims to determine the forms of off-task behavior carried out by students from Islamic boarding schools and general students, knowing the factors that cause as well as the efforts made by classroom teachers to reduce off-task behavior. This research is a type of qualitative research. The research was conducted in 3 schools in Trenggalek regency. The results showed that students from Islamic boarding schools were more likely to carry out off-task behaviors in the category of large problems related to assignments, while general students were more varied and spread across all categories. The factors that cause students to carry out off-task behavior are from the school related to the general condition of the school and the management of the teacher in managing the class, there are factors from the place of residence and from the students themselves. The efforts made by the teacher are different in every type off task behaviour. Teacher is more silent and give advices.

Abstrak: Penelitian ini bertujuan untuk mengetahui bentuk-bentuk perilaku off task yang dilakukan oleh siswa dari pondok pesantren dan siswa umum, mengetahui faktor penyebab serta upaya-upaya yang dilakukan oleh guru kelas untuk mengurangi perilaku off task. Penelitian ini merupakan penelitian kualitatif. Penelitian dilakukan di tiga sekolah di kabupaten Trenggalek. Hasil penelitian menunjukkan jika siswa dari pondok pesantren lebih cenderung melakukan perilaku off task kategori masalah besar terkait dengan tugas, sementara siswa umum lebih bervariasi dan menyebar pada semua kategori. Faktor penyebab siswa melakukan perilaku off task yaitu dari sekolah terkait dengan kondisi umum sekolah dan manajemen guru dalam mengelola kelas, terdapat faktor dari tempat tinggal serta dari diri siswa sendiri. Upaya yang dilakukan guru berbeda pada setiap kategori. Guru lebih banyak membiarkan dan menegur.
\end{abstract}

ABSTRAK

Belajar merupakan kewajiban bagi setiap siswa di sekolah. Proses belajar tidak hanya berlangsung pada lingkup formal, namun juga non formal. Berdasarkan PPRI No 17 pasal 1 tahun 2010 salah satu lembga non formal yaitu majelis taklim yang memiliki kewangan untuk menyelenggarakan program pendidikan yaitu pendidikan keagamaan Islam atau dalam masyarakat lokal disebut dengan pondok pesantren. Perbedan sistem pendidikan pesantren dengan lembaga pendidikan yang lain adalah anak yang mengenyam pendidikan di pondok pesantren akan tinggal di asrama. Di dalam pondok pesantren santri akan belajar endidikan berlandaskan nilai-nilai Islam lengkap dengan norma dan kebiasaan-kebiasaannya (Jaya, 2009; Hidayat, 2016). Berdasarkan hasil observasi dan wawancara yang dilakukan pada beberapa santri di dua pondok pesantren pada bulan Mei 2018 santri cenderung memiliki jadwal yang sangat padat dan disiplin. Kegiatan sudah dimulai sejak dini hari untuk solat malam berjamaah dan berlanjut hingga subuh. Pagi hari santri yang mengenyam pendidikan formal baik SD, SMP maupun SMA akan bersiap pergi ke sekolah untuk memulai belajar ilmu umum. Siang atau sore hari setelah pulang sekolah mereka istirahat sejenak dan bersih diri, lalu kegiatan berlanjut hingga malam hari.

Santri yang bersekolah formal akan membaur dengan siswa-siswa lain dari warga sekitar. Usia anak sekolah dasar tergolong dalam masa anak-anak akhir (Hurlock, 1980). Pada usia tersebut, anak berada pada usia kreatif dan bermain dimana guru harus dapat mewadahi karakteristik-karakteristik tersebut di dalam pembelajaran. Selain itu, anak yang berada pada masa anak-anak akhir juga membutuhkan perhatian yang lebih baik dalam pembicaraan maupun kegiatan (Hurlock, 1980). Meskipun santri dengan siswa umum memiliki usia yang sama, namun mereka memiliki pengalaman dan aktivitas yang berbeda. Siswa umum akan memiliki lebih banyak waktu untuk istirahat, bermain, dan belajar. Selain itu, mereka akan lebih bebas untuk 
mengekspresikan diri secara positif tanpa terikat dengan disiplin yang ketat dari tempat tinggal. Sementara itu, setiap hari santri dibebani oleh kegiatan-kegiatan yang tidak ringan, mulai dari bangun tidur hingga tidur lagi hingga tidak ada waktu yang terbuang percuma (Jaya, 2009).

Perbedaan pengalaman dan lingkungan tempat tinggal siswa meyebabkan berbagai macam perilaku, baik perilaku yang sesuai dengan tujuan pembelajaran (on task) maupun perilaku yang tidak sesuai dengan tujuan pembelajaran (off task). Kegiatan observasi dan wawancara yang dilakukan pada April-Juni 2018 di tiga sekolah, yaitu MIS Jami'atul Ulum, MIS Nuruzh Zholam, dan MIS Plus Darunnajah. Ketiga sekolah tersebut dipilih karena di dalam kelas terdapat siswa dari pondok pesantren dan siswa dari masyarakat umum yang belajar bersama dalam satu kelas. Berdasarkan hasil observasi dan wawancara diketahui masih banyak siswa melakukan bentuk-bentuk perilaku off task, seperti ramai saat guru menjelaskan, melamun dalam kelas, tidak mau mengerjakan tugas, pasif saat kuis atau kerja kelompok, berjalan-jalan dalam kelas, menganggu temannya, keluar kelas tanpa ijin serta, berpindah tempat duduk tanpa izin serta mencontek saat ujian maupun saat mengerjakan tugas. Perilaku-perilaku off task yang dilakukan oleh siswa menyebabkan terjadinya gangguan di dalam kelas (Bluestein, 2013). Perilaku-perilaku tersebut perlu penanganan yang serius dari guru. Perilaku off-task dapat menyebabkan kegagalan dalam kegiatan belajar mengajar dan bahkan dapat menyebabkan siswa tinggal kelas atau gagal dalam belajar. Dalam hal ini guru kelas memiliki peran yang sangat penting. Guru kelas hampir setiap hari melakukan interaksi dengan siswa di kelasnya sehingga memiliki kedekatan tersendiri dengan siswa. Guru harus mampu untuk menciptakan lingkungan pembelajaran yang nyaman sehingga selain sebagai pendidik, guru juga harus mampu memahami permasalahan-permasalahan siswa di kelas agar dapat menentukan respons yang tepat untuk menangani setiap penyimpangan perilaku yang dilakukan oleh siswa.

Berdasarkan uraian tersebut, menjadi penting dan menarik untuk mengungkap bentuk-bentuk perilaku off task pada sekolah-sekolah yang memiliki siswa campuran antara santri dan siswa umum, yaitu MIS Jami'atul Ulum, MIS Nuruzh Zholam, dan MIS Plus Darunnajah. Penting pula untuk menggali lebih jauh faktor-faktor penyebab perilaku off task dan sejauh mana upaya guru dalam menangani perilaku off task yang dilakukan oleh siswa. Agar nantinya dapat menjadi masukan bagi guru dan sekolah supaya lebih bijak dalam menangani perilaku yang terjadi sesuai dengan penyebabnya.

\section{METODE}

Jenis penelitian ini adalah kualitatif dengan rancangan penelitian adalah studi multisitus. Peneliti hadir di lokasi penelitian sebagai pengamat non-partisipan. Penelitian dilakukan di tiga sekolah yaitu MIS Jami'atul Ulum, MIS Nuruzh Zholam dan MIS Darunnajah karena ketiga sekolah tersebut memiliki kelas dengan siswa campuran, yaitu siswa dari pondok pesantren dan masyarakat umum yang belajar bersama dalam satu kelas. Pengumpulan data dari sumber data dilakukan dengan beberapa teknik yaitu observasi, wawancara, dan dokumentasi kepada subjek-subjek terkait.

Analisis data data dalam studi multi situs terdiri dari dua tahap, yaitu analisis data kasus individu dan analisis lintas situs (Yin, 2018; Creswell, 2018). Untuk analisis data situs individu digunakan analisis menurut Miles \& Huberman (Yin, 2018; Emzir, 2016) yaitu pengumpulan data, model data (Meng-coding dan mengelompokkan data), reduksi data, serta refleksi dan penarikan kesimpulan. Keseluruhan kegiatan tersebut dilakukan secara simultan sampai pengambilan data selesai dilakukan (Emzir, 2016; Ulfatin, 2015). Proses analisis dalam situs individu dapat dilihat pada gambar 1. Selanjutnya, temuan dari situs I, II dan III dianalisis secara simultan dengan induksi analitis dalam analisis lintas situs untuk mengonstruksi dan menyusun konsepsi temuan akhir. Alur analisis lintas sistus dapat dilihat pada gambar 2.

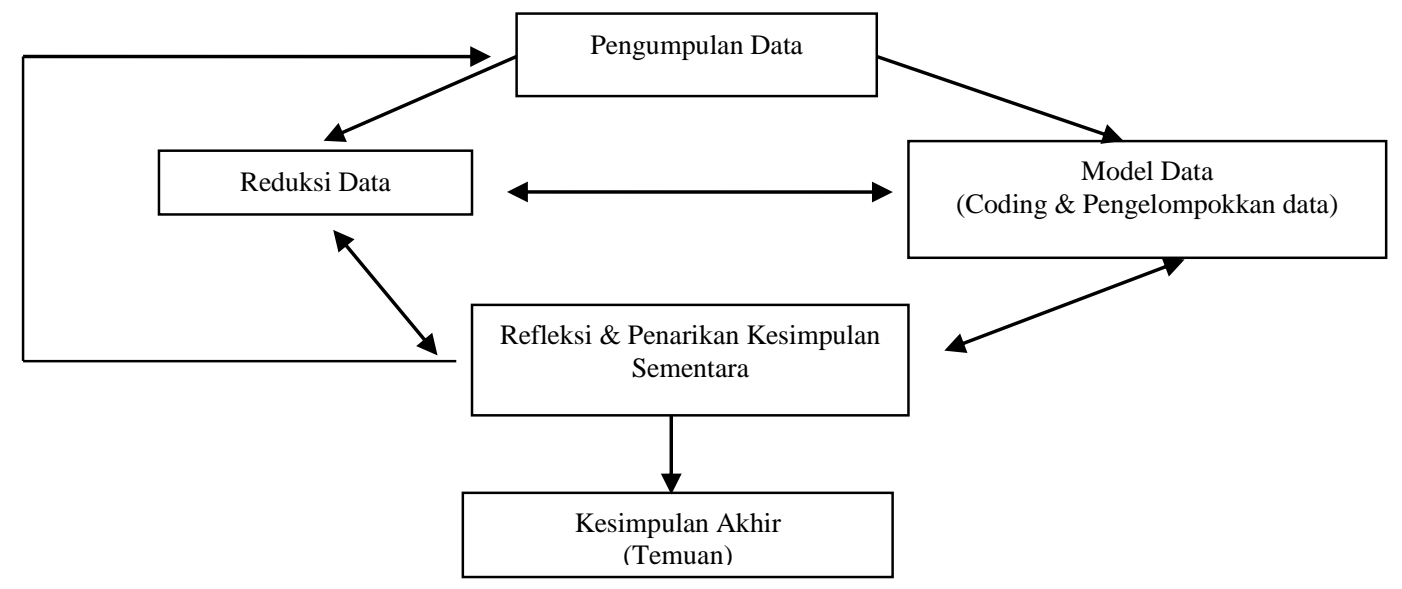

Gambar 1. Alur Analisis Situs Individu (Ulfatin, 2014) 
Situs I

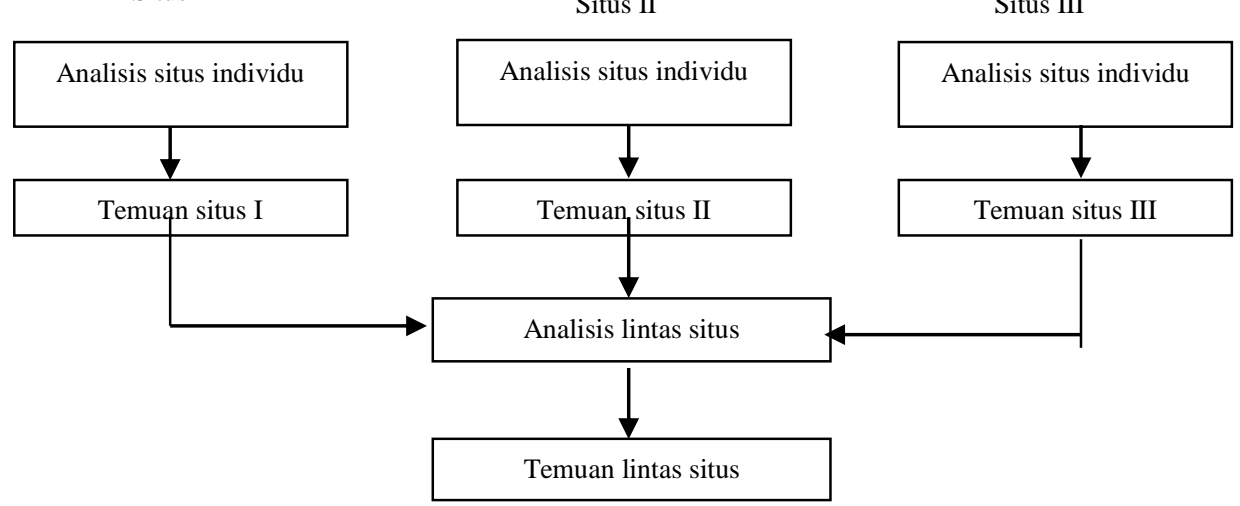

\section{Gambar 2. Alur Analisis Lintas Situs (Olahan Peneliti)}

\section{HASIL}

\section{Bentuk-Bentuk Perilaku Off Task}

Siswa pondok pesantren cenderung untuk melakukan perilaku off task kategori masalah besar yaitu terkait dengan pengerjaan tugas, baik tugas di rumah maupun tugas di sekolah sementara siswa umum melakukan off task merata di semua kategori. Variasi bentuk-bentuk perilaku yang dilakukan juga tergantung pada dominasi siswa di kelas. Antara siswa pondok pesantren dan siswa umum terjadi interaksi yang saling memengaruhi perilaku off task yang dilakukan.

\section{Faktor-Faktor Penyebab Perilaku Off Task}

Perilaku off task yang muncul dapat disebabkan dari beberapa faktor. Faktor yang pertama yaitu berasal dari lingkungan sekolah. Faktor-faktor lingkungan sekolah penyebab perilaku off task yang ditemukan yaitu terkait dengan profil sekolah ada atau tidaknya pondok pesantren pada yayasan yang menaungi sekolah, kondisi sekolah yang strategis, dominasi siswa di kelas apakah siswa pondok pesantren atau siswa umum, asal siswa serta latar belakang keluarga siswa yang beragam, tidak adanya program sekolah mengenai penanganan kebijakan dan batuan dari guru BK, kepala sekolah menyerahkan penanganan perilaku sepenuhnya kepada guru kelas dengan penanganan yang kondisional. Sementara terkait dengan profesionalisme guru dalam memanajemen kelas yaitu tidak adanya proses seleksi yang ketat terkait dengan penerimaan guru, penerimaan guru yang hanya kondisional saja, guru memberikan perhatian berbeda antara siswa pondok dan siswa umum maupun bersikap acuh, penggunaan metode guru kurang bervariasi yaitu lebih sering memakai ceramah dan penugasan, kegiatan siswa monoton, sumber belajar kurang serta tidak adanya media belajar.

Faktor lain yang berpengaruh kuat terhadap belajar anak di sekolah adalah faktor dari lingkungan tempat tinggalnya. Temuan penelitian lintas kasus aspek terkait faktor-faktor ligkungan tempat tinggal penyebab siswa melakukan perilaku off task pada siswa pondok pesantren dan siswa umum dibagi menjadi dua, yaitu lingkungan pondok pesantren dan lingkungan rumah siswa. Lingkungan pondok pesantren yaitu lingkungan yang jam belajarnya kurang lebih satu jam, kurangnya pengawasan saat belajar, jadwal pondok terlalu padat, tidak adanya motivasi belajar yang dilakukan oleh sebagian besar pihak pondok, ada tekanan negatif dari teman saat belajar, dan sebagian pondok tidak ada komunikasi dengan pihak sekolah. Sementara faktor penyebab perilaku off task dari lingkungan tempat tinggal siswa umum yaitu siswa belajar hanya saat ada PR dan ujian, orangtua peduli dengan kemampuan sekolah namun anak sendiri tidak ada keinginan belajar meski didampingi, sebagian orangtua tidak ada komunikasi dengan pihak sekolah. Selain faktor eksternal yang berasal dari lingkungan sekolah dan lingkungan tempat tinggal, faktor internal atau faktor dari dalam diri siswa juga memegang peranan yang penting. Temuan lintas situs terkait faktor diri sendiri penyebab siswa melakukan perilaku off task pada siswa pondok yaitu rendahnya motivasi belajar, kelelahan fisik serta memiliki pengalaman buruk terkait dengan sekolah serta permasalhan terkait keluarga. Sementara pada siswa umum motivasi belajar siswa yang rendah dan adanya pengalaman buruk terkait sekolah.

\section{Upaya-Upaya Guru Kelas untuk Mengurangi Perilaku Off Task}

Guru di kelas melakukan berbagai upaya untuk mengurangi perilaku off task siswa. Temuan penelitian terkait dengan upaya-upaya yang dilakukan oleh guru dalam mengurangi perilaku off task yaitu pada kategori bukan masalah maka guru akan cenderung untuk membiarkan atau mengabaikan, kategori masalah kecil yaitu guru akan menasehati atau menegur, memberikan pertanyaan mendadak dan terkadang membiarkan, kategori masalah besar maka guru akan menegur hingga memarahi siswa, melakukan pembimbingan secara individu, mengancam dengan soal atau nilai serta meminta siswa duduk di depan, kategori memperparah maka guru akan memarahi siswa, menegur dengan intonasi keras. Dalam menanagani perilaku off task guru melakukan berbagai pertimbangan terkait kapan dilakukan, bentuk perilakunya apa serta bagaimana dampak dari perilaku tersebut bagi kelas. Guru juga memberikan perhatian lebih kepada siswa pondok pesantren. Hal ini menimbulkan kecemburuan pada siswa lain serta tidak efektif karena perilaku masih terus dilakukan setiap hari. 


\section{PEMBAHASAN \\ Bentuk-Bentuk Perilaku Off Task}

Perbedaan karakter dan latar belakang siswa akan memunculkan berbagai jenis perilaku pada siswa, khususnya saat pembelajaran di kelas. Pembelajaran di kelas banyak memunculkan respon siswa. Berdasarkan hasil observasi selama dilapangan ditemukan beberapa pola perbedaan perilaku off task yang ditunjukkan oleh siswa yang tinggal di pondok pesantren dan dari siswa umum. Bentuk-bentuk perilaku yang ditunjukkan oleh siswa pondok pesantren yaitu pada kasus satu, dua, dan tiga siswa cenderung melakukan perilaku off task kategori masalah besar terkait dengan penyelesaian tugas baik PR maupun tugas di sekolah. Emmer (2011) menjelaskan perilaku pada kategori masalah besar menganggu dan mengacaukan pembelajaran, namun hanya dilakukan oleh satu atau dua orang saja dan tidak dilakukan secara bersamaan. Kategori ini termasuk pelanggaran aturan kelas atau sekolah yang lebih serius, misalnya memukul siswa lain.

Siswa umum pada situs II dan III lebih tidak memiliki kecenderung tertentu untuk melakukan perilaku off task. Mereka melakukan perilaku pada semua kategori secara merata. Namun pada situs I perilaku off task oleh siswa umum yaitu cenderung melakukan perilaku off task kategori masalah besar dengan variasi perilaku yang lebih banyak. Perilaku-perilaku tersebut yaitu berbicara dengan teman satu bangku atau teman di belakangnya saat guru menjelaskan, bermain saat jam pelajaran, menyontek, berjalan-jalan di kelas, pasif saat diskusi, bertengkar dengan temannya, tidak segera mengerjakan tugas, melamun, pinjam meminjam alat tulis diserta bercanda dan lain-lain. Perilaku-perilaku tersebut termasuk dalam kategori off task karena tidak sesuai dengan tujuan pembelajaran serta menganggu pembelajaran. Hasil temuan tersebut sama seperti yang ditemukan oleh Shofufah (2016) dan Bintari (2017) terkait dengan bentuk-bentuk perilaku off task yang dilakukan oleh siswa yaitu berjalan-jalan dalam kelas, berbicara dengan teman, bermain, tidak memperhatikan penjelasan guru hingga tidak mengerjakan tugas atau PR, melamun serta berpindah tempat duduk. Selain itu, Beserra (2019) menyebutkan jenis-jenis perilaku off task, yaitu melamun, melihat hal lain selain pelajaran, bermain alat tulis, berbicara di luar topik pembelajaran, dan menganggu teman sekelas.

\section{Faktor-Faktor Penyebab Perilaku Off Task}

Terdapat banyak sekali alasan mengapa siswa berperilaku buruk. Lingkungan dapat mendorong siswa untuk berperilaku baik maupun buruk (Cowley, 2010). Pada salah satu sekolah kelas masih perlu untuk dibenahi karena tidak ada jendela serta daun pintu, listrik juga belum dipasang sehingga menggangu pelajaran. Hal ini sesuai dengan pernyataan Cowley (2010) dan Elstad (2016) bangunan, fasilitas di sekolah serta sarana dan prasarana dari sekolah merupakan salah satu yang paling berpengaruh di kelas dan dapat menimbulkan perilaku-perilaku tertentu seperti off task. Selain terkait dengan kondisi fisik sekolah dan kelas, kondisi siswa juga akan menentukan perilaku siswa. Latar belakang siswa yang beragam akan membuat kebutuhan siswa yang juga beragam. Setiap siswa merupaka individu yang menarik dan kompleks (Djabidi, 2016). Dominasi jumlah siswa baik dari siswa pondok pesantren maupun dari siswa umum di kelas membuat perilaku off task siswa di kelas meningkat. Hal ini disebabkan kebutuhan berbeda dari siswa tidak dapat terpenuhi. Kebanyakan perilaku tidak produktif siswa adalah respon dari siswa yang kebutuhan dasarnya tidak terpenuhi dalam lingkungan dimana perilaku tersebut muncul (jones, 2012). Belum adanya penanganan perilaku secara tertulis serta menyerahkan penanganan perilaku kepada guru kelas secara penuh menyebabkan penanganan perilaku off task siswa tidak efektif. Etos keseluruhan dari lingkungan akan memiliki dampak yang kuat bagi perilaku di kelas. Guru kelas juga belum mengetahui secara lebih jauh tehnik-tehnik dan strategi dalam menangani perilaku-perilaku tersebut secara efektif (Mahabbati, 2006).

Guru kelas merupakan guru yang paling efektif dan strategis dalam membantu siswa di kelas serta menunjukkan tanggung jawab ketika setiap orang di sekolah mampu memahami tanggung jawab serta bekerja sama (Jones, 2012). Kegiatan belajar mengajar di kelas tidak akan terlepas dari metode belajar, serta media dan sumber belajar. Pemilihan metode pembelajaran situs III berbeda dengan situs I dan II. Situs I dan II cenderung menggunakan penugasan dan ceramah dalam pembelajaran dan sangat jarang menggunakan metode-metode belajar yang lain. Sementara pada situs III guru lebih kreatif dan menggunakan beragam metode sesuai dengan materi pembelajaran sehingga siswa juga lebih menikmati pembelajaran. Dengan menggunakan metode ceramah dan penugasan tanpa ada variasi lain akan membuat siswa cepat bosan dan pasif (Putri, 2016; Enawati, 2013; Godwin et al., 2016; Latief Sahidin dan Dini Jamil, 2013). Pengaturan tmpat duduk situs I dan III siswa memilih sendiri tempat duduknya sementara situs III tempat duduk diubah setiap minggu. Pengaturan tempat duduk memiliki keterkaitan dengan motivasi belajar siswa di kelas. Hasil penelitian oleh Rohmanurmeta \& Farozin (2017) serta Rahmat Setiyadi \& Deni Ramdani (2016) menunjukkan bahwa terdapat pengaruh yang positif dan signifikan variasi gaya pengaturan tempat duduk terhadap motivasi dan hasil belajar peserta didik. Tempat duduk siswa yang monoton dan tidak adanya pengaturan tempat duduk oleh guru membuat siswa jenuh dalam belajar dan siswa hanya akan dekat dengan beberapa siswa tertentu saja. Ketiga situs tidak pernah atau jarang sekali menggunakan media belajar. Guru serta siswa yang sangat jarang menggunakan media dan hanya belajar dari LKS akan membuat siswa merasa jenuh dalam belajar di kelas sehingga muncul rasa bosan, ketidak puasan serta komunikasi hanya berjalan satu arah (Brahim, 2007; Rahina, 2007).

Pengaruh lingkungan tempat tinggal juga tidak kalah penting dari lingkungan sekolah. Lingkungan tempat tinggal siswa baik yang tinggal dengan orangtua di rumah maupun siswa yang tinggal di pondok pesantren sangat memengaruhi proses pendidikan siswa di sekolah. Siswa yang tinggal di lingkungan pondok memiliki jadwal yang lebih padat dan jam belajar yang lebih sedikit. Siswa yang tinggal di pondok pesantren rata-rata hanya memiliki waktu terjadwal satu jam untuk belajar, 
pengawasan belajar yang kurang, dan banyaknya tekanan negatif negatif saat belajar misalnya teman-teman yang mengajak bermain atau mengobrol saat belajar karena mereka belajar secara bersama-sama. Selain itu, pihak pondok pesantren kurang memberikan motivasi siswa untuk berprestasi di pendidikan formal. Pada situs II antara pihak sekolah dan pondok pesantren tidak pernah melakukan komunikasi sehingga pihak pondok pesantren tidak mengetahui bagaimana perkembangan anak di sekolah.

Berbeda lingkungan tempat tinggal berbeda pula permasalahan yang dialami oleh anak dalam hal belajar. Siswa umum tinggal di rumah bersama dengan keluarga. Siswa-siswa ini seharusnya mendapatkan perhatian yang lebih serta mendapatkan pengawasan langsung dari orangtua maupun pihak keluarga yang lain. Namun, pada kenyataannya berdasarkan sampel yang diambil dari ketiga situs siswa jarang belajar di rumah, siswa hanya belajar jika ada PR atau ujian saja. Beberapa pihak keluarga peduli dengan pendidikan anak di sekolah dan memarahi anak jika tidak belajar, namun ada juga keluarga yang diam saja dan mentolerir anaknya ketika tidak belajar. Pada situs I dan situs II orangtua sangat jarang berkomunikasi dengan pihak sekolah atau guru kelas atau bahkan tidak pernah, kecuali saat perkumpulan wali murid di sekolah. Hal tersebut menyebabkan pembelajaran siswa tidak dapat berjalan maksimal karena tidak ada dukungan dari keluarga di rumah. Hasil di observasi tersebut sependapat dengan pernyataan Cowley (2010) menyebutkan tiga faktor mengapa seorang siswa dapat berperilaku buruk, yaitu (1) orangtua siswa memiliki pengalaman buruk ketika mereka sekolah dan menyampaikan hal tersebut kepada anak, (2) dukungan untuk belajar di rumah kecil atau bahkan tidak ada, dan (3) terdapat prospek luar biasa di luar pendidikan di wilayah tersebut.

Banyak alasan mengapa anak melakukan perilaku off task di sekolah. Selain terkait dengan faktor-faktor eksternal, ada pula faktor internal penyebab siswa melakukan perilaku off task. Persamaan dari data yang diambil dari siswa pondok pesantren dan siswa umum adalah rendahnya motivasi belajar. Motivasi sangat berpengaruh penting terhadap pemelajaran, karena tanpa adanya motivasi maka meskipun anak berada di kelas yang secara umum nyaman dan semua faktor belajar mendukung, anak tetap tidak akan bias belajar dengan baik. Pernyataan ini juga sejalan dengan penelitian dari Juniarti (2015) yang menyebutkan salah satu faktor instriksik siswa menurunya prestasi belajar adalah malas yaitu siswa hanya menganggap belajar adalah sebuah kewajiban tanpa dibarengi niat dan minat untuk memperhatikan, tidak belajar di rumah merupakan sebuah hal yang wajar serta meremehkan PR maupun tugas dari guru karena belum memahami fungsi PR atau tugas yang diberikan.

Faktor instrinsik lain yang dialami siswa baik di pondok pesantren maupun siswa umum yaitu adanya pengalaman buruk di sekolah sebelumnya serta memiliki masalah di keluarga. Pengalaman buruk di sekolah serta permasalahan di keluarga akan membuat siswa merasa tidak nyaman berada di sekolah dan malas untuk belajar. Pernyataan ini sesuai dengan penelitian oleh Nursalim (2018) yaitu banyak siswa yang mogok sekolah yang dipicu oleh peristiwa traumatis, seringkali tidak mau lagi mendengar, bersentuhan, beraktivitas yang berhubungan dengan sekolahnya. Lebih jauh lagi dapat memberikan dampak negatif yang besar bagi perkembangan kognitif, perkembangan fisik dan psikososial anak sehingga kehidupan akademik, personal maupun sosialnya terganggu. Faktor instrinsik lain yang ditemukan yaitu adanya kelelahan fisik serta mengalami permasalahan di lingkungan keluarga. Selanjutnya, terkait dengan kelelahan fisik yang dialami oleh siswa pondok akibat dari banyaknya kegiatan yang diikuti oleh siswa sejalan dengan penelitian Netrasari 2015) yang menyebutkan salah satu faktor internal siswa pondok perperilaku agresif adalah adanya kelelahan fisik akibatnya siswa menjadi mudah tersulut emosinya.

\section{Upaya-Upaya Guru Dalam Mengurangi Perilaku Off Task}

Dalam upaya mengurangi perilaku off task, guru melakukan beberapa upaya tergantung kepada beberapa hal yaitu perilaku apa yang dilakukan oleh siswa, siapa pelakunya, kapan melakukannya serta seberapa besar dampak yang ditimbulkan dari perilaku tersebut baik bagi iklim kelas maupun bagi teman-temannya. Dalam mengurangi perilaku off task kategori bukan masalah guru cenderung untuk membiarkan atau mengabaikan. Upaya guru dalam mengurangi perilaku off task kategori masalah kecil adalah dengan menegur siswa yang bersangkutan serta memberikan pertanyaan secara mendadak. Namun pada situs II dan III guru juga cenderung untuk mengabaikan masalah kecil tersebut. Upaya guru dalam menangani perilaku off task kategori masalah besar yaitu guru akan memarahi siswa yang bersangkutan, guru berkeliling kelas, mengancam siswa baik dengan nilai, melakukan bimbingan secara individu hingga meminta bantuan dari guru lain untuk membantu mengatasi kenakalan siswa.

Sementara itu, untuk kategori memperparah maka guru akan memarahi siswa secara keseluruhan, guru mengancam memberikan soal sulit kepada siswa, mengambil barang atau mainan yang digunakan siswa serta menegur siswa dengan nada dan intonasi keras. Berdasarkan hasil observasi selama di lapang peneliti melihat upaya yang dilakukan guru kurang efektif dan efisien. Perialku off task siswa tetap terjadi setiap hari dan dilakukan oleh siswa-siswa yang sama. Siswa juga tidak merasa jera dan terus mengulangi setiap hari. Perlakuan khusus kepada siswa pondok pesantren yang dilakukan pada situs pertama dan ketiga justru menimbulkan kecemburuan bagi teman-teman sekelasnya dan membuat siswa yang lain merasa diabaikan. Hal tersebut dikarenakan guru terfokus membantu siswa-siswa tertentu, siswa yang mengalami kesulitan dalam mengerjakan tugas menjadi enggan untuk bertannya.

Pengurangan perilaku off task tidak dapat dilakukan secara kondisional terus menerus. Seorang guru harus memikirkan cara yang efektif untuk mengurangi perilaku tersebut atau bahkan melakukan kerjasama dengan BK untuk kasu-kasus tertentu. Salah satu factor perilaku off task berasal dari guru dan sekolah. Maka guru dan sekolah perlu melakukan upaya-upaya untuk mengurangi perilaku off task siswa. Pengurangan perilaku off task yang dapat dilakukan oleh guru yaitu penggunaan metodemetode tertentu seperti mengajari anak untuk menentukan sikap atas suatu hal secara mandiri (Luke, Vail, \& Ayres, 2014), dengan menggunakan video game edukasi (Beserra et al., 2019; Flower 2014), melakukan metode bercerita (Sabourin, 2011), melakukan evaluasi ulang terhadap tingkat kesukaran tugas dan kemampuan siswa (Hawkins, 2008). Selain itu, guru juga perlu 
memahami penyebab siswa melakukan perilaku tersebut, bisa jadi hal tersebut dikarenakan siswa perlu untuk menyalurkan emosi-emosi negatif dalam dirinya. Pernyataan tersebut sesuai dengan pendapat (Rush, 2017) faktor penyebab perilaku off task bukan hanya berasal dari lingkungan, namun juga dari diri siswa sendiri. Faktor yang ditemukan terkait dengan siswa yaitu motivasi belajar rendah, adanya traumatis pada siswa serta masalah keluarga. Hal-hal semacam ini memerlukan bantuan dari pihak-pihak tertentu untuk membantu guru, salah satunya adalah guru BK.

Bimbingan dan konseling di sekolah dasar bertujuan untuk mengembangkan sikap spiritual, emosional, dan keterampilan secara berimbang (Ramli, 2016). Oleh karena itu, guru dan sekolah dapat menentukan langkah yang tepat untuk membantu siswa mengatasi masalahnya. Selain itu, anak-anak berkebutuhan khusus perlu adanya strategi serta metode khusus seperti melakukan aktivitas fisik sambil belajar agar anak lebih menikmati (Godwin et al., 2016). Swoszowski (2013) juga menyatakan jika anakanak yang megalami gangguan belajar harus ada metode khusus, misalnya belajar setengah hari saja dengan tugas-tugas tersendiri untuk mengurangi beban dan perilaku off task tanpa melupakan peran guru untuk memotivasi.

\section{SIMPULAN}

Berdasarkan fokus penelitian dan temuan serta analisis lintas situs, maka dapat disimpulkan sebagai berikut. Pertama, poa bentuk perilaku off task siswa dari pondok pesantren yaitu siswa cenderung melakukan perilaku off task kategori masalah besar terkait dengan penyelesaian tugas, baik tugas-tugas di sekolah maupun tugas-tugas di rumah. Sementara siswa umum melakukan perilaku pada semua kategori secara merata.

Kedua, faktor-faktor penyebab siswa melakukan perilaku off task. Faktor pertama yaitu faktor lingkungan sekolah dibagi menjadi dua, yaitu kondisi umum sekolah dan profesionalisme guru kelas dalam managemen kelas. Aspek kondisi umum yaitu terkait dengan profil sekolah ada atau tidaknya pondok pesantren pada yayasan yang menaungi sekolah, kondisi sekolah yang strategis, dominasi siswa di kelas apakah siswa pondok pesantren atau siswa umum, asal siswa serta latar belakang keluarga siswa yang beragam, tidak adanya program sekolah mengenai penanganan kebijakan dan batuan dari guru BK, kepala sekolah menyerahkan penanganan perilaku sepenuhnya kepada guru kelas dengan penanganan yang kondisional. Sementara aspek profesionalisme guru kelas dalam managemen kelas yaitu tidak adanya proses seleksi yang ketat terkait dengan penerimaan guru, penerimaan guru yang hanya kondisional saja, penggunaan metode guru kurang bervariasi, kegiatan siswa monoton, sumber belajar kurang serta tidak adanya media belajar. Faktor kedua yaitu faktor dari lingkungan tempat tinggal. Faktor dari tempat tinggal siswa umum yaitu siswa belajar hanya saat ada PR dan ujian, orangtua peduli dengan kemampuan sekolah, namun anak sendiri tidak ada keinginan belajar meski didampingi, sebagian orangtua tidak ada komunikasi dengan pihak sekolah. Sementara faktor dari pondok pesantren yaitu jam belajar kurang, kurangnya pengawasan saat belajar, jadwal pondok terlalu padat, tidak adanya motivasi belajar yang dilakukan oleh sebagian besar pihak pondok, ada tekanan negatif dari teman saat belajar serta sebagian pondok tidak ada komunikasi dengan pihak sekolah. Faktor ketiga yaitu faktor dari diri siswa sendiri pada siswa umum dan siswa pondok pesantren. Faktor penyebab siswa melakukan perilaku off task pada siswa umum dan pondok sama yaitu motivasi belajar siswa yang rendah, adanya pengalaman buruk terkait dengan sekolah, serta siswa yang mengalami kesulitan belajar (slow learner) yang sering membedakan adalah kelelahan fisik dan masalah keluarga yang rentan terjadi pada anak pondok pesantren.

Ketiga yaitu upaya guru dalam mengurangi perilaku off task siswa. Bukan masalah maka guru akan cenderung untuk membiarkan atau mengabaikan. Kategori masalah kecil yaitu guru akan menasehati atau menegur, memberikan pertanyaan mendadak dan terkadang membiarkan Kategori masalah besar maka guru akan menegur hingga memarahi siswa, melakukan pembimbingan secara individu, mengancam dengan soal atau nilai serta meminta siswa duduk di depan. Kategori memperparah maka guru akan memarahi siswa secara keseluruhan, menegur dengan intonasi keras serta mengancam. Dalam menanagani perilaku off task guru melakukan berbagai pertimbangan terkait kapan dilakukan, bentuk perilakunya apa serta bagaimana dampak dari perilaku tersebut bagi kelas. Guru juga memberikan perhatian lebih kepada siswa pondok pesantren. Upaya-upaya yang dilakukan oleh guru tersebut dinilai kurang efektif karena siswa masih terus melakukan perilaku tersebut setiap harinya dan bahkan menimbulkan kecemburuan dan kesenjangan pada siswa-siswa tertentu.

Pendidik disarankan untuk lebih memahami karakter setiap peserta didiknya serta menyebarluaskan kesadaran kepada masyarakat bahwa keterlibatan orangtua pada pendidikan anak sangat penting. Pendidik juga diharapkan dapat saling berbagai ilmu mengenai pengelolaan kelas yang sesuai dengan karakter siswa di kelas. Pendidik jangan segan-segan untuk melakukan konsultasi atau meminta bantuan pihak-pihak terkait jika siswa mengalami gangguan perilaku, gangguan sosial maupun kesulitan belajar di kelas.

\section{DAFTAR RUJUKAN}

Beserra, V., Nussbaum, M., \& Oteo, M. (2017). On-Task and Off-Task Behavior in the Classroom: A Study on Mathematics Learning with Educational Video Games. Journal of Educational Computing Research, 0(0) 1-23.

Bintari, M. E. (2017). Teknik Penguatan Positif Dalam Mengurangi Perilaku Off Task di Sekolah Dasar Negeri Kaliasin VI Surabaya. Jurnal Pendidikan Bimbingan dan Koseling, 7(1), 1-12.

Bluestain, J. (2013). Manajemen Kelas. Jakarta: PT Indeks. 
Brahim, T. K. (2009). Peningkatan Hasil Belajar Sains Siswa Kelas IV Sekolah Dasar, Melalui Pendekatan Pemanfaatan Sumber Daya Alam Hayati di Lingkungan Sekitar. Jurnal Penabur, 6(9), 37-49.

Cowley, S. (2010). Panduan Manajemen Perilaku Siswa. Jakarta: Erlangga

Creswell, J. (2018). Penelitian Kualitatif \& Desain Riset Edisi 3. Yogyakarta: Pustaka Pelajar

Djabidi, F. (2016). Manajemen Pengelolan Kelas. Malang: Madani.

Enawati, S. (2008). Pengaruh Penggunaan Metode Konseptual Dalam Bimbingan Praktik Klinik Keperawatan terhadap Pencapain Kompetensi. Tesis tidak diterbitkan. Universitas Sebelas Maret, Surakarta.

Emzir. (2016). Metodologi Jurnal BK UNESA Penelitian Kualitatif Analisis Data. Jakarta: Rajawali Pers.

Elstad, E., Arnesen, T., \& Christophersen, K. (2016). What Explains Pupils' Perceived Motivational Conflict Between Academic Work and Off-Task Behavior In Technology-Rich Classroom?. Digital Expectations and Experiences in Education, 10, 59-75.

Evertson, C. M., \& Emmer, E. T. (2011). Manajemen Kelas untuk Guru Sekolah Dasar. Jakarta: Kencana Prenada Media Group.

Godwin, K. E. Almeda, M.V. Seltman, H., \& Kai, S. (2016). Off Task Behavior in Elementary School Children. Learning and Instruction, 44(4), 128-143.

Hawkins, R. O., \& Axelrod, M. (2008). Increasing the On-Task Homework Behavior of Youth with Behavior Disorders Using Functional Behavioral Assessment. Behavior Modification, 32(6), 840 - 859.

Hidayat, N. (2016). Implementasi Pendidikan Karakter melalui Pembiasaan di Pondok Pesantren Pabelan. Jurnal Pendidikan Sekolah Dasar, 2(1), 128-145.

Jaya, H. D. A. (2009). Perbedaan Penyesuain Diri Santri di Pondok Pesantren Tradisional dan Modern. Tesis tidak diterbitkan, Universitas Negeri Surakarta, Surakarta.

Jones, V., \& Jones, L. (2012). Manajemen Kelas Komprehensif Edisi ke 9. Jakarta: Kencana.

Juniarti, N., Bahari, Y., \& Riva'ie, W. (2015). Faktor Penyebab Menurunnya Hasil Belajar Siswa pada Pembelajaran Sosiologi di SMA. Jurnal Pendidikan dan Pembelajaran, 4(2), 1-11.

Luke, S. Vail, C O., \& Ayres, K. M. (2014). Using Antecedent Physical Activity to Increase On-Task Behavior in Young Children. Exceptional Children, 80(4),489-503.

Mahabbati, A. (2016). Identifikasi Anak dengan Gangguan Emosi dan Perilaku di Sekolah Dasar. Jurnal Pendidikan Khusus, $2(2), 1-14$.

Netrasari, E. (2015). Studi Kasus Perilaku Agresif Remaja di Pondok. Jurnal Riset Mahasiswa Bimbingan dan Konseling, 5(4), $1-10$.

Nursalim, M. (2018). Kemanjuran Konseling BESCB (Brief Ego State Cognitive- Behavioral) untuk Mengurangi Mogok Sekolah pada Siswa Sekolah Menengah Atas. Tesis tidak diterbitkan. Unversitas Negeri Malang, Malang,

Nugrahani, R. (2007). Media Pembelajaran Berbasis Visual Berbentuk Permainan Ular Tangga untuk Meningkatkan Kualitas Belajar Mengajar di Sekolah Dasar. Journal of Educational Research: Lembaran Ilmu Kependidikan, 36(1), 350 — 44.

Peraturan Pemerintah Republik Indonesia Nomor 17 Tahun 2010. Pengelolaan dan Penyelenggaraan Pendidikan.

Putri, L. A. (2016). Penerapan Metode Think Pair Share dengan Teknik Permainan Kata Kunci untuk Meningkatkan Keterampilan Membaca Dalam Menemukan Pikiran Pokok (Penelitian Tindakan Kelas di Kelas IV SDN Tegalkalong III, Kecamatan Sumedang Utara, Kabupaten Sumedang). Tesis tidak diterbitkan. Universitas Pendidikan Indonesia, Bandung.

Rohmanurmeta, F. M., \& Farozin, M. (2016). Pengaruh Pengaturan Tempat Duduk terhadap Motivasi dan Hasil Belajar pada Pembelajaran Tematik Integratif. Jurnal Penelitian Ilmu Pendidikan, 9(1), 70-82.

Rush, K. S., Golden, M. E., Mortenson, B. P., Albohn, D., \& Horger, M. (2017). The Effects of a Mindfulness and Biofeedback Program on the On and Off-Task Behaviors of Students with Emotional Behavioral Disorders. Contemporary School Psychology, 21(4), 347-357.

Sabourin, J. (2011). When Off-Task is On-Task: The Affective Role of Off-Task Behavior in Narrative-Centered Learning Evironments. Artificial Intelligence in Education, 6738, 534-536.

Sanusi, U. (2012). Pendidikan Kemandirian di Pondok Pesantren (Studi Mengenai Realitas Kemandirian Santri di Pondok Pesantren al-Istiqlal Cianjur dan Pondok Pesantren Bahrul Ulum Tasikmalaya). Jurnal Pendidikan Agama IslamTa'lim, 10(2), 123-139.

Ulfatin, N. (2015). Metode Penelitian Kualitatif di Bidang Pendidikan: Teori dan Aplikasinya. Malang: Media Nusa Kreatif. 